\title{
THE POLITICAL SCRIMMAGE OF THE RELIGIOUS COURT'S LAW AS THE JUDICIAL INSTITUTION IN THE REFORMATION ERA IN INDONESIA
}

\author{
Erie Hariyanto \\ (Shari'a Department of STAIN Pamekasan, Jl. Raya Panglegur km. 04 Pamekasan, \\ Email:erie@stainpamekasan.ac.id) \\ Made Warka \\ (Faculty of Law of Universitas 17 Agustus 1945 Surabaya, Email: \\ warka@untag.ac.id)
}

\begin{abstract}
:
Religious court as one of the four court environments is a special court for Moslems with its special authority scope also, either about its matter or its justice seekers (justiciabel). During twice of law changing in the reformation era, the court authority in the religious court's environment is widened, this is suitable with the law development and the society's need of law, especially Moslems. Although it has been ten years that the law of religious court is legitimated (2006-2016) but there are still problems in the authority of the religious court in the reformation era, some of them are the material law factor, where there has been no material laws and specific judicial procedure in the religious court environment. The factor of law politic of the Supreme Court (MA) as the highest institution should have given more attention to religious courts by synchronize the law regulation about special authority had by the religious court, and the third factor is cultural law in society which waits for the professionalism and integrity of the religious court in taking the new responsibility mainly in solving the Islamic economy dispute
\end{abstract}

Key Words:

Religious Court System, Reformation Era, Judicial Institution, Islamic Economy

Abstrak:
Peradilan agama sebagai salah satu dari empat lingkungan peradilan,
merupakan lembaga peradilan khusus yang ditujukan kepada umat
Muslim dengan lingkup kewenangan yang khusus pula, baik
mengenai perkaranya maupun para pencari keadilannya (justiciabel).

al-Ihkâm Vol.11 No.1 Juni 2016

DOI: http://dx.doi.org/10.19105/al-ihkam.v11i1.782 
Dalam dua kali perubahan undang-undang di era reformasi, kewenangan pengadilan di lingkungan peradilan agama semakin diperluas, hal ini sesuai dengan perkembangan hukum dan kebutuhan hukum masyarakat, khususnya masyarakat Muslim. Walaupun sudah sepuluh tahun undang-undang peradilan agama disahkan (2006- 2016), namun problematika kewenangan Pengadilan Agama di era reformasi masih saja ada di antaranya adalah faktor materi hukum belum ada hukum materiil dan acara khusus di lingkungan pengadilan agama, Faktor politik hukum Mahkamah Agung sebagai lembaga tertinggi semestinya memberikan perhatian yang lebih kepada peradilan agama yaitu dengan melakukan singkronisasi peraturan perundangan-undangan mengenai kewenangan khusus yang dimiliki peradilan agama, dan faktor ketiga budaya hukum masyarakat menunggu profesionalitas dan integritas lembaga peradilan agama dalam mengembangan amanah kewenangan baru utamanya dalam penyelesaian sengketa ekonomi Islam.

\section{Kata-kata Kunci:}

Sistem Peradilan Agama, Era Reformasi, Lembaga Yudisial, Ekonomi Islam

\section{Introduction}

In building law system, besides keeping the existing law, which is the colonial law, there are still other sources of law which are suitable with the Indonesian characteristics, which is Common Law and Religious Law, especially Islamic Law. By using those three law systems, this country can choose its own model and philosophy of the National Law which is suitable with the Nation characteristics in formulizing a National Law System.

When the independence of Indonesia was declared in August 17, 1945, it shows the transition from the rule of Colonial Law to the rule of National Law, so since that time this nation had the right and authority to choose its own path and free from other nations' intervention. And also since that time, this nation has the right and authority to fulfill this independence in all sides which is suitable with the nature and characteristics of its society. Therefore, the construction in all fields is started, either physically or non-physically. 
Actually, that construction is also the construction of Indonesian society totally.

Conceptually, it was seen that after the reformation happened there is a changing on the direction of clear law development, which is trying to formulize a National Law through unification and codification process. This unification and codification programs have not been successful yet, then it seems that it was not suitable with the nation because the program seems to refer to continental Europe. Therefore, up to this point the process of law development openly done, means the changing process of the rest of colonial law is fixed to the society's need and want through the formulation of the law rule.

The development of the Law Nation concept which is adopted by The 1945 Statute Law starts to change because the influence of globalization in all fields. The concept of law nation comes from the country of Anglo Saxon known as rechtsstaat will not always the same as the rule of law. According to Friedmann law nation in the meaning of rechtsstaat usually used by law expert in West Europe countries such as Immanuel Kant and Frederich Julius Stahl. Rechtsstaat means that there is a restriction on the nation authority by the law.

Law Nation according to rechtsstaat concept has elements: acknowledgement of human rights or groundrechten, the differentiation on the authority or sceiding van machten, the governmental system based on then statute law or wetmatigheid van het bestuur, administration court law or rechtspraak. ${ }^{1}$ According to A.V. Diccey the concept of rule of law, has some elements: supremacy of law, equality before the law; constitution based on humanright. Generally, countries of West Europe adopted civil law system or Germany Rome and countries of Anglo Saxon adopted common law system.

The precept of trias politica divided the nation authority into legislative authority or an authority to formulize statute law, executive or an authority to do the statute law and judicial authority or an authority to judge the violation on the statute law. ${ }^{2}$ The 1945 statute law amendment chapter 1 paragraph (3) states that Indonesia is a Law Nation. As the rule applies, so one of the important

\footnotetext{
1 Jimly Assiddiqie, Agenda Pembangunan Nasional di Abad Globalisasi (Balai Pustaka: Jakarta, 1988), 80.

2 Miriam Budiardjo, Dasar-Dasar Ilmu Politik (Jakarta: Gramedia, 1987), 151.
} 
principles of the Law Nation is that there is a guarantee on the implementation of jurisdiction department which is free from the interference of extrajudicial authority side to organize the court to uphold the rule, the justice, the truth and the legal certainty that can give the society protection.

The change of the 1945 Statute Law has changed the constitutional, especially in the implementation of the court institution's authority. An independent Judiciary authority is a pillar of an independent country. An independent authority is an authority which is impartial and free from the executive influence and free from the disturbance in doing their tasks. An independent authority has minimally five elements. They are: there is no political interference in designing the functionary in the court institution, there is a certain time for the position and salary, there is no intervention from the executive and legislative in the process of the adjudication, there is autonomy in the administration and there is a sufficient budget. An independent and autonomous judiciary authority is the universal goal as stated in: "Basic Principles on the Independenceof Judiciary" and has been a decision in $7^{\text {th }}$ Congress of United Nation about the Prevention of Crime and the Treatment of Offenders. ${ }^{3}$

According to M. Yahya Harahap, an independent authority has a purpose: there is a certainty on the implementation of the function and the honest and impartial court authority or to ensure a fair and just trial and that the court has a role to oversee all the government doings or the ruler or to enable the judge to exercise control over the government action. ${ }^{4}$ According to 1945 Statute Law chapter 24 paragraph (1), the judiciary authority is an independent authority to implement the court system to uphold the law and justice. Chapter 24 paragraph (2), the judiciary authority is done by a Supreme Court and the court institution underneath which is still under the authority of general court system, the religious court environment, the martial court environment, state administration court and a constitutional court. The role and function of the religious court as the practitioner

\footnotetext{
${ }^{3}$ Romli Atmasasmita, Reformasi Hukum: Hak Asasi Manusia dan Penegakan Hukum (Bandung: Mandar Maju, 2001), 3.

${ }^{4}$ M Yahya Harahap Beberapa Tinjauan tentang Permasalahan Hukum (Bandung: Citra Aditya Bakti, 2004), 253.
} 
of the judiciary authority is to apply and uphold the law and justice based on Pancasila and 1945 Statute Law. ${ }^{5}$

The embodiment of the independent authority as it is mandated by the 1945 Statute Law has been set about the court system, as it set in the Law No. 48 of 2009 about the judiciary authority, general court system as it is set in the Law No. 2 of 1986 deals with the Law No. 8 of 2004 and the law no 49 of 2009, Religious court is set in the Law No. 7 of 1989. The law No. 3 of 2006 and the Law No. 50 of 2009, the State Administration Court is set in the Law No. 5 of 1986 deals with the law No. 9 of 2004 and the law No. 47 of 2009 and the Constitutional Court as has been set in the Law No. 31 of 1997.

In a country which has announced as a law country including Indonesia, they need to do some changes in the court system. This is happening because if the court performance is good so it will produce qualified court institution's decisions and those qualified decisions will become the law sources which will be used in society and country environment. As we know that the three court environments, they are religious court, martial court, and the state administration court, by the description of the Law No. 48 of 2009 are called as special court because they judge special cases as the rule of the law said. Martial court for instance: according to the Law No. 31 of 1997 judging the criminal case whose doer is the military member.

The calling of Special Court by the description of the law, the judiciary authority is not for the purpose to give special idiosyncrasy to the citizen who will be judged. This only shows the difference of those three court environments with the general court which has a wider and more general authority. This breadth authority is caused by the two kinds of affairs which are the criminal affairs and civil affairs.

Religious court as one of the four court environments is a special court institution which is intended to the Moslems with its special authority scope also, either about its matter or its justice seekers (justiciabel). ${ }^{6}$ The development of religious court in Indonesia

${ }^{5}$ Ahmad Mujahidin, Peradilan Satu Atap di Indonesia (Bandung: Refika Aditama 2007), 2.

6 Abdul Ghofur Anshori, Peradilan Agama di Indonesia Pasca UU No. 3 Tahun 2006:

Sejarah, kedudukan, dan Kewenangan (Yogyakarta: UII Press, 2007), 1. 
has taken place before the independence of Indonesia; even it also happened in the period of the Islamic kingdom. The judge at that time was called qhadi who was mainly diviner who was given authority by the king or sultan in charge to handle civil cases or criminal cases in the society.

Before the application of the Law No. 7 of 1989 about Religious court, the same authority of religious court in Indonesia is on Marriage Law, as it is stated in Chapter 63 Paragraph 1 in the Law No. 1 of 1974 . According to the law, the religious court has the authority in the field of Moslems marriage. However, the Chapter 63 Paragraph 1is weakened by the $2^{\text {nd }}$ Paragraph which states that every religious court decision must be legitimated by the district court.

Therefore, religious court needs to ask a legal force from the district court to apply its decision (executoir verklaring). One of the causes of this regulation is because at that time, the religious court did not have bailiff as the district court has. It shows that before the application of religious court law, the religious court has not had the same position as other courts. By the existence of religious court law, there is also a unity in the law which organizes the religious court in the national legal framework and the rule of law. Thus, Moslems who becomes the biggest resident of Indonesia has been given a chance to obey the rule if Islamic law which becomes the absolute teachings in their religion. ${ }^{7}$

Religious court as one of four court environments under the Supreme Court, in 2006 has a strategic additional authority that is judging the Islamic economy dispute. This begins when the Law No. 3 of 2006 about the changing of the Law No. 7 of 1989 about religious court is legitimated. ${ }^{8}$ The existence of the amendment to the religious court law is based on the emergence of the new law which is the Law No. 4 of 2004 about the judicial authority as an organic law to Chapter 24 of the 1945 Statute Law after the amendment with one roof system. From the above description can be understood that the position and the function of the religious court is equal to other court institutions as one of the state judiciaries that carrying out the legal authority in

\footnotetext{
${ }^{7}$ Mohammad Daud Ali and Habibah Daud, Lembaga-lembaga Islam di Indonesia (Jakarta: RajaGrafindo Persada, 1995), 120.

${ }^{8}$ Mardani, Hukum Acara Perdata Peradilan Agama (Jakarta: Sinar Grafika 2007), 65.
} 
judiciary field, with the main function is to uphold the law and the justice based on Pancasila.

\section{Judicial Institution in Indonesia}

In the judiciary authority of Indonesia firmly states that there is a court institution which is independent and free from any ruler and any part of institution, implementing the fast, easy, cheap and open court process and also free from the corruption, collision, and nepotism. Those instructions and policy are suitable with the typical characteristics of a law nation, they are: first the confession and the protection to the human rights, which contains the equality in politic, law, social, economy and culture; second the free and impartial justice which is not influenced by any authorities or any other powers; third the legality in all forms. ${ }^{9}$

Some experts said that there is no absolute separation from the three legal powers but the world society has realized that the judicial independence is very important in the process of judiciary. As the member of the United Nation, we are bounded to the principle which was received by the United Nation. So besides we receive it rationally, we need to obey the mutual agreement that has been taken in the general conference in $1948 .{ }^{10}$

The constitution country of Indonesia is before the existence of the changing of the 1945 Statute Law about the freedom in judiciary is also confirmed in the explanation Chapter 24 and 25 the 1945 Statute Law is "the judicial authority is a free authority, means apart from the influence of the governmental power. Accordingly, there must be guarantee in the law about the position of the judges which exists in the third changing of the 1945 Statute Law. The formulation is set in the Chapter 24 which states that the judicial authority is a free authority to implement the court system to uphold the law and justice. Specifically independence judiciary in the broad meaning consists of these things:

\footnotetext{
9 Bambang Waluyo, Implementasi Kekuasaan Kehakiman Republik Indonesia (Jakarta: Sinar Grafika, 1992), 3

10 Ibid.
} 
1) The court has unlimited jurisdiction to all the issues related to the court system and must have authority to state whether the current issues are in its authority scope as it is ordered in the law;

2) The court must guarantee that the process judiciary should be done honestly and the right of people (who are in the cases) should be respected and protected;

3) The protection to the human right of the judges in doing their responsibility especially in facing accusation in order to do their duty;

4) Recruitment matter, selection, mutation, training and judge's promotion;

5) The discipline establishment to the judges and payroll.11

Start from the above resolution substances shows that The United Nation did not see the matter of "independence judiciary" as an independent problem and separated from the influences of 3M factors (man, money and materials) so that it can be said that the goal of "independence judiciary" must be supported by those factors. Support from these three factors does not mean and not mutatis mutandis show that there is an executive influence because there is a strict separation between administration authority in broad sense (court administration) as it has been mentioned above and the judiciary authority in the narrow sense (judicial) ${ }^{12}$ In carrying out the judiciary authority.

The independence of the judiciary institution is the main characteristic of democracy country, so that the judge must be free from all intervention in doing his judicial duty, moreover the judge is also bounded with some basic principles which support the realization of the independence and the professionalism of the judge in doing his judicial functions, they are:

1) The religious principle/divinity principle, for instance in every decision the judge make always started with the word "for the justice based on the God all mighty", this statement gives a big

\footnotetext{
11Romli Atmasasmita, Reformasi Hukum, Hak Asasi Manusia dan Penegakan Hukum (Bandung: Mandar Maju, 2001), 3 - 4.

12Ibid.
} 
implication, because the judge in judging a case must be responsible to the God also, not only to humans;

2) Dealing with the code of conduct, the judge in doing his duty is bounded to the judge's profession code of ethic;

3) Law of positive, is a rule which is stated by a legal authority and its application can be forced as the name of law;

4) Society life, where a judge must dig, follow, understand law values and the sense of justice lives in the society.

Dealing with his duty to uphold the law and justice, there should be an independent judicial in one side, and there is also a human weakness of a judge in another side so the rule for the judge to obey the law and the statute law regulation is a means to keep the judicial independence in a balanced situation. This balance is also give the judge to function fairly because the judge as a substance or guidance should be stiff, firm, or rigid. However, the law will be not inhumanly if it is only read as the way it is, therefore the role of a judge is as a balancing between the firmness and the wisdom so that it can be fulfilled the ancient maxim which say: fortiter in rei, suafier in modo (firm in principles, wise in the implementation). Therefore by this way the law through the judge decision can be implemented with full of wisdom and can be applied fairly. ${ }^{13}$

According to me, there is a difference in the freedom of the judge in examining and deciding the case, especially the judge who handle the civil case and the judge who handle criminal case. The criminal case is more focused on the thing that is being demanded by the prosecutor only, while the civil judge is more free in examining and deciding the case because in every claim or appeal that is addressed to his request is always added ex aequo et bono, if the court has another opinion, please give the fair decision. Meanwhile, Shimon Street divided the independence of the judiciary into four, they are:

1) Substansive Independence (the independence in deciding a case);

2) Personal Independence (for instance there guarantee on the term of office and tenure);

3) Internal Independence (for instance the independence from the employer and the officemate);

${ }^{13}$ Gunarto Suhardi, Menegakkan Kemandirian Yudisial (Yogyakarta, Universitas Atmajaya Yogyakarta, 2006), 60. 
4) Collective Independence (for instance there is a participation in the court administration, including the determination of the court's budget). ${ }^{14}$

The independence of the judicial institution should also be followed by the independence of the judge, because the judge is a determinant in the judicial process. In doing his duty a judge must be free from the government's influence and other influences, as it is stated in Chapter 2 Law No. 3 of 2009 related to the Law No. 5 of 2004 related to the Law No. 14 of 1985 about the Supreme Court which states that the Supreme Court is the highest state court from other court environments, which when they do their duty they are free from the government's influence and other influences.

Besides in the Law of Supreme Court, there is also stated in the law about the court institutions under the Supreme Court that the judge freedom in examining and deciding the case cannot be interfered either by the direct supervisor or the government or others, as it is stated in the Chapter 53 Paragraph (5) Law No. 49 of 2009 about the second changing of the Law No. 2 of 1986 as it has been changed with the Law No. 8 of 2004 about the general court, Chapter 7 and Chapter 52 Paragraph 4 Law No. 5 of 1986 as it has been changed with the Law No. 9 of 2004 and then it was changed again to the Law No. 51 of 2009 about the administrative court, Chapter 5 Paragraph 3 and Chapter 12E Paragraph 3 the Law No. 7 of 1989 about the religious court as it has been changed and added by the Law No. 3 of 2006 and was changed again with the Law No. 50 of 2009 about the religious court system and Chapter 7 Paragraph 2 the Law No. 31 of 1997 about the martial justice.

Conceptually or practically, it was admitted that there is a close relationship between democracy and the Nation based on the Law with an independent and free judicial authority. Without an independent judiciary authority, and a free judge, there will be no democracy and law based Nation. An independent judiciary authority and a free judge is one characteristic even it is a requirement for a democracy law-based Nation. But actually this relationship should not only be done one way (eenzijdig or one sided) which say that the

14 Blue Print of the Renewal of Supreme Court of Indonesia of 2003, 4. 
authority of an independent judiciary and free judge is a pillar of democracy and Law based Nation. The same rule happens for the reverse version. Democracy and law based Nation as a function or requirement as the existence and the guarantee for an independent judiciary authority and the freedom of the judge. ${ }^{15}$ In the constitutions that have been implemented in the Indonesia also mentioned about the independent judiciary authority, there are:

1) The 1945 Statute Law, explanation Chapter 24 which states that: "the judiciary authority is an independent authority, means it is apart from the government authority. Deals with that, there must be a guarantee in the law about the judge position;

2) Constitution of Indonesia Union of 1949, part 2 Chapter 145 Paragraph 1 stated that: "all interventions, however it is, by no means of judiciary means, is forbidden, except if it is permitted by the law";

3) Temporary statute law of 1950, part 3 Chapter 103 stated that: "all interventions in the judiciary matters by any means which is not a judiciary means, is forbidden, except it is permitted by the law";

4) The result of the three changing of the 1945 Law, Chapter 24 Paragraph 1 explained that: "A judiciary authority is an independent authority to apply a court system to uphold the law and the justice."16

The intervention from other country, especially from the government, to the judiciary institution in Indonesia in the process of getting the independent judiciary authority is caused by many factors, they are:

1) In the past time, the politic authority is very strong and dominant (executive heavy) systematically tried to weaken the other country's authority. (legislative and judiciary)

2) The judge recruitment system, especially the recruitment of Supreme Court and the leaders of Supreme Court mostly consist of political elements and deny the transparent,

15 Bagir Manan, Kekuasaan Kehakiman Indonesia dalam UU No. 4 Tahun 2004 (Yogyakarta: FH UII Press, 2007), 15.

16 Ibid. 
participative, trusted and based on merit system recruitment process. In the Chapter 8 of the Law No. 14 of 1985 states that the president has the authority to choose and remove the Supreme Court and the leaders of the Supreme Court, while the parliament (DPR) has the authority to propose the candidate of the Supreme Court.

3) There is no guarantee that the Supreme Court has no authority on the sufficient budget to do his role, which can also decrease the Supreme Court independence. In Chapter 2 Law No. 5 of 1973 about the Audit Board of The Republic of Indonesia states that the government and the parliament that the authority to decide the budget for the Supreme Court through budget and state revenues, while the supervision to the management of the fund is done by the Audit Board. ${ }^{17}$

The judicial institution will be stronger if there is a united or integrative and non-discriminate judicial institution, because in this kind of judicial institution, they will get a total support from the citizen of a country. A non-discriminate judiciary system is a no impartial judiciary in another word the judges will be independent and not dependent on something else or interfered by anybody. Therefore non- discriminate judiciary is also a solid judiciary and has a strong judicial independence.

Judicial independence, that should be kept and fight for, which is also known as institutive independence, means an independence from other institutions' interference. In Indonesia, institutive independence has been supported by the strongest law rule which is the statute law Chapter 24 Paragraph 1 and in the Law No. 48 of 2009 about the judiciary authority.

In the process of enforcing and upholding the law is not merely for the law itself, there is another component that can support the implementation and the upholding of the law. The law is nothing if there is no support from these components. The process of working the law is influenced by three important components which is related each other as it is described in model of law and development by Robert B. Seidman stated that the components to make the law work consists of three elements which is related each other and influence

17 Blue Print of The Supreme Court, 47. 
each other, they are the law making processes, law implementing processes, and the role occupant. 18

Talking about the system in implementing the judiciary authority in Indonesia today should refer to the 1945 Statute Law that has been amended. Based on the provision Chapter 24 the 1945 Statute Law that has been amended stated that:

1) The judiciary authority is an independent authority to implement the judiciary to uphold the law and justice;

2) The judiciary authority that was done by the Supreme Court and the court institutions under it in the general court environment, religious court environment, martial court environment, the administrative court environment, and by a constitutional court;

3) Other institutions that have the function related to the judiciary authority are set in the law.

The provision of Chapter 24, 1945 Law that has been amended is analogous with the provision Chapter 1 and Chapter 2 the Law No. 4 of 2004 about the judiciary authority which stated that:

Chapter 1: the judiciary authority is an independent Nation authority to enforce the judicial process to uphold the law and justice based on Pancasila, for the true implementation of the Law Nation of Indonesia.

Chapter 2 : the implementation of the Judiciary authority as it is intended in Chapter 1 was done by a Supreme Court and the court institution under it in the general court environment, religious court environment, martial court environment, the administration court environment, and by a Constitutional Court.

The provision Chapter 24 The 1945 Statute Law and the provision chapter 1 and 2 the Law No. 4 of 2004 about the judiciary authority which is quoted above, besides affirming about the position and the function of the judiciary authority, it is also affirming about the implementer of the judiciary authority from the judiciary authority itself in Indonesia today.

18 Robert B. Seidman, The State Law and Development (Now York: St. Martin's Press, 1978), 75-77. 
In the provision of chapters quoted above it is affirmed that the judiciary authority is an independent Nation authority. From the provision above can be understood that the judiciary authority is one of the Nation authority Institution or Nation organizer institution besides people's consultative assembly (MPR) the president, people's representative assembly (DPR) and the legal audit institution (BPK) which has the main function to enforce the judiciary to uphold the law and justice based on Pancasila. The judicial authority is independent in doing its function, means it is free from the government' interference. ${ }^{19}$

The implementer or the administrator of the judiciary authority as it is affirmed in the provision quoted above is the Supreme Court and the judiciary institution under it in the general court environment, religious court, martial environment, administrative court, and the constitutional court. This is also reaffirmed in Chapter 10 Paragraph 1 and 2 the Law No. 4 of 2004 which state that: (1) The judiciary institution is done by the Supreme Court and the judicial institution under it, and also by a constitutional court. (2) The court institutions under the Supreme Court consist of any judicial institution in the general court environment, religious court, martial court, and legal administrative court.

Based on the rule provisions in the law quoted above, the implementation system of the judicial authority in Indonesia is not the same as before, where the judicial authority is only implemented by a Supreme Court and the judicial institution under it. Based on the provision in the 1945 Statute Law that has been amended and the law about the judicial authority as it is quoted above, the ruler or the administrator of the judiciary authority in Indonesia today, besides it is done by the Supreme Court and the judicial institution under it in the general court environment, religious court, martial environment, administrative court, and a constitutional court.

Apart from the institutional difference as it is described above, those judicial institutions stand on their own feet. In the enforcement

${ }^{19}$ In the explanation Chapter 1 the Law No. 4 of 2004 is stated that an independent judicial authority means that the judicial authority is free from any interference from the side of the extra judicial power, except the one that has been mentioned in the 1945 Statute Law of Indonesia. 
of the judicial authority has the same and equal position and function, there must be no subordination, they are as the state court and also the implementer of an independent judicial authority to enforce the law and the justice.

The difference among court institutions is only in the jurisdiction section to which a law is given. In another word, the difference between one court institution and others among the implementers of the judicial authority is only on the cases that is being solved, it must be suitable with the law had set. From the above explanation it can be understood that the position and the function of the religious court is as the same as other court institutions which is as one of the legal court which implement legal authority in judicial side, with the main function is to enforce law and the justice based on Pancasila.

\section{Politic of Law in Religious Court in the Reformation era}

To know the law position of the religious court institution, we need to understand the formulation in Chapter 19 the Law No. 48 of 2009 on the judicial authority which is replacing the Law No. 4 of 2004. The religious court is also set in the Law. No 7 of 1989 about the religious court as it has been changed again to the Law. No 3 of 2006 and it was changed again into the Law No. 50 of 2009. The religious court is a court for Moslems. This court is one of the implementer of the judicial authority to Moslems who look for the justice about the special civil cases which is set in the Chapter 2 the Law No. 50 of 2009 related to the Law No. 3 of 2006 related to the Law No. 7 of 1989.

Operationally in the field of the religious court environment is done by the religious court as the first level of the judiciary, the Religious High Court as the appellate level and the highest level of it is on the Supreme Court. One thing that is interesting of the religious court is that the authority matters. In twice of law changing, the authority of the court in the religious court environment is widened; it is suitable with the law development and the people's law need, especially Moslems. The expansion covers the Islamic economy. In the relation to this law changing, the sentence in the general explanation of the religious court which states; "all parties before proposing the case can consider choosing what law that is used in the distribution of inheritance", is stated to be deleted. 
Therefore, by the emergence of the Law No. 3 of 2006 which is then changed into the Law No. 50 of 2009, so all the Heir cases which covers Moslems, become the absolute authority of the religious court. for the clear explanation about the cases that can be examined/ judged by the religious court can be seen in the Chapter 49 the Law No. 50 of 2009 related to the Law No. 3 of 2006 related to the Law No. 7 of 1989. The religious court has a responsibility to examine, decide and solve the cases in the first level among Moslems in the field of: (a) Marriage, (b) Heritage, (c) Last Will, (d) Gift, (e) Waqf, (f) Zakat (g) Infaq (h) Shadaqah, and (i) Islamic economy.

The explanation of Chapter 49: the settlement of the dispute is not restricted only in the sharia banking field, but also in other Islamic economy fields. The meaning of "among Moslems" is also include people or law institution if they are freely follow the Islam law about the things that is being the responsibility of the religious court in accordance with the rule of this Chapter. The explanation of the "I" word in the Islamic economy is an act or activity which is done as the Islamic principle included: (a) Islamic Bank (b) Islamic micro fund institution, (c) Islamic Insurance, (d) Islamic Reinsurance, (e) Islamic mutual Guard (f) Islamic obligation and securities with the Islamic middle period (g) Islamic security, (h) Islamic mode of financing, (i) Islamic pawnshop, $(\mathrm{j})$ retire fund of the Islamic fund institution and (k) Islamic Business.

The Law No. 7 of 1989 which has been changed twice takes off many rules about the regulation about religious court that has been implemented in Indonesia, they are;

1) The regulation about the religious court in Java and Madura (Staatsblad of 1982 No. 152 and Staatsblad of 1937 No. 116 and No. 610).

2) The regulation about the density of the Qadlî and the density of the big Qadlî to some part of South Kalimantan and East Kalimantan residence (Staatsblad of 1937 No. 638 and No. 639)

3) The government regulation No. 45 of 1957 about the formation of religious court/Islamic Supreme Court outside Java and Madura (legal institution of 1957 No. 99)

4) The regulation as it is meant by Chapter 63 Paragraph (2) the Law No. 1 of 1974 about marriage (legal institution of 1974 No. 1 additional legal paper No. 3019). 
The arrangement of religious court is determined by the Chapter 9 Paragraph (10) the Law No. 50 of 2009 related to No. 3 of 2006 related to the Law No. 7 of 1989 which consist of: the leader/ chief, the judges, secretary, and the Bailiff. Procedural law that is applied in the court in the religious court environment is the civil procedural law of the general court environment, except the one which is already specially set in the Law No. 7 of 1989 as it has been changed with the Law No. 3 of 2006 and it was changed again into the Law No. 50 of 2009.

For the court of the appellate level is the Religious High Court, its duty and responsibility is determined in Chapter 51 the Law No. 50 of 2009 related to the Law No. 3 of 2006 related to No. 7 of 1989, the High Court has role and responsibility:

1) The Religious High Court has the duty and responsibility to judge cases which become the responsibility of the religious court in the appellate level. The intended religious court authority is in the field of marriage, heritage, last will, and gift which are done through Islamic law, as well as waqf and shadaqah. The religious court authority is also be the authority of Religious High Court.

2) The Religious High Court is also on duty and be responsible to judge in the first and the last level of the dispute and it also to judge among the religious court in its law scope. This competency is called a relative competency.

The arrangement in the Religious High Court is arranged as the provision Chapter 9 Paragraph (2) the Law No. 50 of 2009 related to the Law No. 3 of 2006 related to the Law No. 7 of 1989, they are: the chief of the judges, registrar and secretary. The religious court consists of first, the religious court as the first level of the court which is situated in the capital of a city and its law environment covers the regency/city, but it does not mean that there is an exception. Second the Religious High Court as the appellate level court which is situated in the capital of a province and its law environment covers province regency. ${ }^{20}$

${ }^{20}$ Mardani, Hukum Acara Perdata, 65. 
The religious court power based on the Law No. 3 of 2006 is wider than the one which is arranged in the Law No. 7 of 1989. The judicial system as one of the court institutions where the implementer of the judiciary authority has a duty to enforce law and justice to people who seek for a special case, among Moslems, in the field of marriage, heritage, last will, gift, waqf, zakat, infaq, shadaqah, and Islamic economy.

The affirmation on the religious court authority is meant to give basic law to the religious court in solving those special cases. Also to the violation to the law of marriage and its rules of the implementation, also to strengthen the law foundation of Islamic Supreme Court in enforcing the authority in jinâyah which is based on qanûn.

The Islamic positive basic law is expected to be more solid with the Law No. 3 of 2006, because it has deleted law choices. The past religius court law stated in the general explanation that: "before all parties propose a case, they should consider the law with which they will use in the division of the heirs." In the Law No. 3 of 2006 the formulation is deleted.

The Law No. 3 of 2006 is a change of the Law No. 7 of 1989. The past law status is stated in the Chapter 106A with the formulation as follows: when the law is still effected, the regulation of the rule as the implementer of the Law No. 7 of 1989 about the religious court is still be effected as long as it is not contrary and has not been changed yet.

The changed Chapters are Chapter 2 so that it was formulated as follows: "the religious court is one of the implementer of judiciary authority for the Moslems law seekers about special cases as meant by this law." The change is in the word "special case". In the Law No. 7 of 1989 it stated "the special civil cases". The deletion of the word "civil" means that the religious court should not have the competency on the civil cases only. The criminal case which is based on the Islamic rule as it is applied in the province of Nanggroe Aceh Darussalam can be solved in the Islamic Supreme Court which is the special court system from the religious court.

The development of Islamic economy which uses the syarî'ah principles which basically known in the traditional economy, now it start to reach the activity in modern economy such as banking, the 
stock market, insurance, retire fund, etc. Actually the trade principles, renting things, leasing, deposit which are suitable to be implemented in the modern economy activities.

The existence of those things which is supported by the law field, is in the place where the regulation rule as in the Law No. 3 of 2004 about Indonesian Bank and the Law No. 10 of 1998 about the changes of the Law No. 7 of 1992 about banking, the Law No. 19 of 2008 about the Nation Islamic securities and the Law No. 21 of 2008 about the Islamic banking which is strengthen the mature and modern Islamic economy activities today. ${ }^{21}$

Through this Law No. 3 of 2006 the economic problems becomes the competency of the religious court. Besides, it is also permitted to the parties to choose an alternative way as through discussion, mediation, even arbitration. The religious court is one of the implementers of the judicial authority to the Moslems who seek for the justice about special cases as it is meant by this law. ${ }^{22}$

Because in fact in the past time the religious court only has the authority on the family aw, as the marriage, divorce, reconciliation, heritage, heirs. So to which it was given a new authority to receive, check, and decide the dispute problems in the Islamic economy field. This Islamic economy dispute becomes a new authority because actually the authority of the religious court is solving the dispute among Moslems in the civil cases besides the authority in the marriage, heritage, last will, gift, waqf, infaq, and shadaqah. Until now, there is no Islamic economy cases which are enrolled to the religious court but if there is a proposal to solve the Islamic economy cases, the judges are ready to solve and it s actually the role of the judge to wait for the case (passive).

After the implementation of the Law No. 3 of 2006, the parties who did the Islamic principles (in Islamic economy) cannot choose the law to judge the case in another court institutions. Moreover, as it is stated in the general explanation of the Law No. 3 of 2006 Paragraph 2 , the law choice is deleted, even it needs time for the religious court

21 Afdol, Legislasi Hukum Islam di Indonesia (Surabaya: Airlangga University Press, 2006), 115.

22 Chapter 2, the Law No. 3 of 2006 about the explanation on the changing of the Law No. 7 of 1989 about the religious court. 
to receive this responsibility, therefore the contracts between the customer with the Islamic Banking side should have been put the kausula if there is a dispute can be solved in the religious court.

By the existence of the Law No. 3 of 2006, the religious court should be ready to the new responsibility to solve the dispute in the Islamic economy field. The response from the society to the readiness of the religious court in taking the responsibility to solve the dispute in the Islamic economy is still mostly hesitant, related to the law culture of the society especially the doer in the Islamic economy and the law politic of the Supreme Court which the most important thing is to prepare the support to the regulation of the rule.

The problem on the religious court authority in solving the dispute in the field of Islamic economy is a law material in the form of the regulation of the rule, where there is another law besides the Law No. 3 of 2006 about the religious court; it is the Law No. 19 of 2008 about the securities of the Islamic nation and the Law No. 21 of 2008 about the Islamic banking which is enough to be the basic for the implementation of the authority itself because it is completed with explanation in all rules, but in fact, this law is contrary to the law applied before it, the Law of Arbitration, the Law of Stock Market, the Law of Bankrupt, the Law of Insurance system, the Law of Commerce, the Law of Pawning, the Law of Indonesian Bank, the Law of Banking, the Law of Burden, the Law of Fidusia Assurance, the Law of Limited Company, the Law of the Company's documents, the Law of Notary Public Position, the Law of Trade Competition (anti-monopoly), the Law of Customers" Protection, the Law of Economic Enterprise, the Law of the Loan Security and deals with the authority of the fund's service.

Related to the settlement of the dispute in the Islamic banking system, the main issues are, first the law of Burden Right (the Law No. 4 of 1996). This law accommodate a guarantee in the form of a land/ building when in the execution process the debtor lost his performance, it can be done a hidden or through a legal court auction on the Burden Right. Can a religious court also accommodate an auction of the burden right someday by understanding that the legal court has done it also and it can create duplication. Second, the law of the guarantee on the Fenusia requires the making of guarantee certificate for the Fidusia and the application must be in the Fidusia 
office so that it can create the preference of the creditor. The implementation of the Fidusia_execution is also similar to the law of Burden Right. Can the religious court accommodate that?

The third is the law of Bankrupt. The condition of the bankrupt is the debtor has 2 or more creditors, has a loan that already hits its deadline and can be claimed for._The application for the bankrupt is sent to trade court. Therefore can the religious court be functioned as the Islamic judiciary to receive a proposal of bankrupt? That's become a problem.

Politic of Law of the Supreme Court as the highest institution in solving the dispute between the judiciary institutions should take a concrete step dealing with the rule of implementing the law, even in the process there is a court of law circulated letter which is overlapped and the mechanism in solving the dispute in Islamic economy can be done by three judicial institutions, they are the religious court, legal court and BASYARNAS is clearly weakened the existence of the Law No. 3 of 2006 and the Law No. 21 of 2008 therefore there must be a clear mechanism in solving the Islamic economy dispute, which is by returning the problem to the religious court as the institution which has the authority to solve the dispute in the Islamic economy.

The third factor is the law cultural factor. It has been ten years since the Law No. 3 of 2006 is legitimated but there is no will from the effected parties to optimize the duty and the authority of the religious court after the formulation of the Law No. 3 of 2006 about the religious court system in solving the dispute in Islamic economy. This is seen from the deal certificate in the Kausula that if there is a dispute in the society it still need to be solved through BASYARNAS and or the state court, therefore the politic will from the society of Islamic economy has not believed on the religious court authority in solving the dispute of Islamic economy.

\section{Conclusion}

Conceptually and practically, it is admitted that there is a close relationship between democracy and law-based Nation with an independent judicial authority and the free judges. Without the independent judiciary authority, and a free judge there will be no democracy and law-based Nation. An independent judiciary 
authority, and a free judge is a characteristic and even it is a requirement of a democracy country which is based on the law. Indepedence of the judicial institution must be followed by the independence of the judge, because the judge is the determinant in the judicial process. In doing his duty, a judge should be apart from the government's interference and any others', as it is stated in the Chapter 2 Law No. 3 of 2009 related to the Law No. 5 of 2004 related to the Law No. 14 of 1985 about the Supreme Court that states the Supreme Court is a highest legal court from other court environments, and while it is doing its duty it is free from the government' interference and any other interference.

The religious court as one of the four judicial environments is a special judicial institution which is intended for Moslems in the specific scope of authority also, either about its cases or the seeker of the justice (justiciabel). The religious court is a court to Moslems. This court is one of the implementer of the judicial authority to Moslems who look for the justice about special civil cases which is set in the Chapter 2 the Law No. 50 of 2009 related to the law No. 3 of 2006 related to the Law No. 7 of 1989. In twice changing of the law in the reformation era, the judiciary authority in the religious court environment is widened; this is suitable with the development of the law and the people's need on the law, especially for Moslems.

Although it has been ten years that the law of religious court is legitimated (2006 - 2016) but the problems on the religious court's authority still can be found in this reformation era, some of them are the law material factor. There has not been a special law material and the special procedure in the religious court environment. Law Political factor, the Supreme Court as the highest institution should give more attention on the religious court by synchronize the rule of the law about special authority that the religious court has, and the last factor is law cultural factor. The society waits for the professionalism and integrity of the religious court law institution in taking a new responsibility mainly on the solving of the Islamic economy dispute.

\section{Bibliography:}

Afdol, Legislasi Hukum Islam di Indonesia, Surabaya: Airlangga University Press, 2006. 
Erie Hariyanto

Anshori, Abdul Ghofur. Peradilan Agama di Indonesia Pasca UU No. 3 Tahun 2006: Sejarah, kedudukan dan Kewenangan. Yogyakarta: UII Press, 2007.

Assiddiqie, Jimly. Agenda Pembangunan Nasional di Abad Globalisasi. Jakarta: Balai Pustaka, 1988.

Atmasasmita, Romli. Reformasi Hukum: Hak Asasi Manusia, dan Penegakan Hukum. Bandung: Mandar Maju, 2001.

Blue Print of the Renewal of Supreme Court of Indonesia of 2003.

Budiardjo, Miriam. Budiardjo, Dasar-dasar Ilmu Politik. Jakarta: Gramedia, 1987.

Daud Ali, Mohammad and Daud, Habibah. Lembaga-lembaga Islam di Indonesia. Jakarta: RajaGrafindo Persada, 1995.

Harahap, M Yahya, Beberapa Tinjauan tentang Permasalahan Hukum, Bandung: Citra Aditya Bakti, 2004.

Manan, Bagir. Kekuasaan Kehakiman Indonesia dalam UU No. 4 Tahun 2004. Yogyakarta: FH UII Press, 2007.

Mardani. Hukum Acara Perdata Peradilan Agama. Jakarta: Sinar Grafika 2007.

Mujahidin, Ahmad. Peradilan Satu Atap di Indonesia. Bandung: Refika Aditama, 2007.

Seidman, Robert B. Seidman, The State Law and Development. New York: St. Martin's Press, 1978.

Waluyo, Bambang. Waluyo, Implementasi Kekuasaan kehakiman Republik Indonesia.Jakarta: Sinar Grafika, 1992. 